\title{
PEMBUATAN APLIKASI PEMBELAJARAN AKOR DASAR GITAR
}

\author{
Julius Saint Michael Lalela ${ }^{(1)}$,Yeni Rokhayati ${ }^{(2)}$ \\ Teknik Informatika, Politeknik Negeri Batam \\ Jl.Ahmad Yani, Batam Kota, Kota Batam, Kepulauan Riau, 2946 I, Indonesia \\ Email: (I) JULIUS.33III01078@student.polibatam.ac.id, (2)yeni@polibatam.ac.id
}

\begin{abstract}
Abstrak
Every person is now easier to express themselves through music. Many music-themed applications can be found on smartphones, including those based on Android. With the rapid development of smartphone technology nowadays, more and more applications are used as learning media. With the rapid development of technology, an application that can help a beginner guitarist learn basic guitar chords, their shape and tone, is needed. Therefore, an application was developed to facilitate beginner guitarists to learn basic guitar chords. In making this application, the software used consisted of Adobe Flash CS5, Adobe Air, Android Emulator, Android SDK, Adobe Photoshop CS6, and Sound Recorder application. This application had been tested and successfully implemented to facilitate beginner guitarists to learn basic guitar chords, along with their shape and tone.
\end{abstract}

Keywords : smartphone, Android, chord

\section{PENDAHULUAN}

Belajar bermain gitar tidak hanya berfungsi untuk memuaskan diri sendiri tetapi dapat pula digunakan dalam pergaulan sehingga tidak sedikit yang merasa perlu untuk bisa bermain gitar. Gitar adalah alat musik petik yang terbuat dari kayu dan logam. Umumnya, gitar yang digunakan dalam musik populer memiliki enam senar yang disetem pada nada E (rendah), A, D, G, B, E (tinggi), berturut-turut dari senar keenam (senar paling atas dengan ukuran paling besar) ke senar pertama (senar paling bawah dengan ukuran paling kecil). Namun, sebagian besar orang hanya mengenal akor gitar yang umum digunakan saja, misalnya akor mayor. Akor mayor dan minor merupakan akor yang harus dipelajari oleh semua gitaris pemula. Namun, biasanya para gitaris pemula masih mengalami kebingungan dalam membedakan kedua akor ini.

Setiap orang kini lebih mudah dalam mengekspresikan diri melalui musik. Seiring perkembangan teknologi yang pesat saat ini dibutuhkan sebuah aplikasi yang dapat membantu gitaris pemula untuk mempelajari akor dasar gitar dan mengenali bunyinya. Bagi seorang gitaris pemula, mempelajari sendiri akor gitar dari buku tidaklah mudah. Kurangnya pengalaman dalam mengenali bunyi nada dasar akor gitar menyebabkan kesulitan dalam menentukan benar atau tidaknya bunyi nada akor gitar yang dimainkan. Selain itu, masih banyak yang mengalami kesulitan untuk mencocokkan akor gitar dengan nada. Banyak gitaris pemula yang yang memainkan sebuah lagu dengan berpedoman pada akor gitar yang beredar di situs-situs tanpa memikirkan kecocokan nada dengan akor gitar sehingga kurang nyaman didengar. Akor adalah kumpulan nada yang membentuk suatu 
rangkaian yang dimainkan secara bersamaan atau terpisah yang berfungsi untuk mengharmonisasikan gabungan nada-nada tersebut menjadi lebih serasi. berfungsi sebagai ritem atau pengiring lagu.

Tiap nada mempunyai jarak (rentang) yang berbeda dari suatu nada ke nada lainnya, yang diilustrasikan dalam gambar 1 berikut:
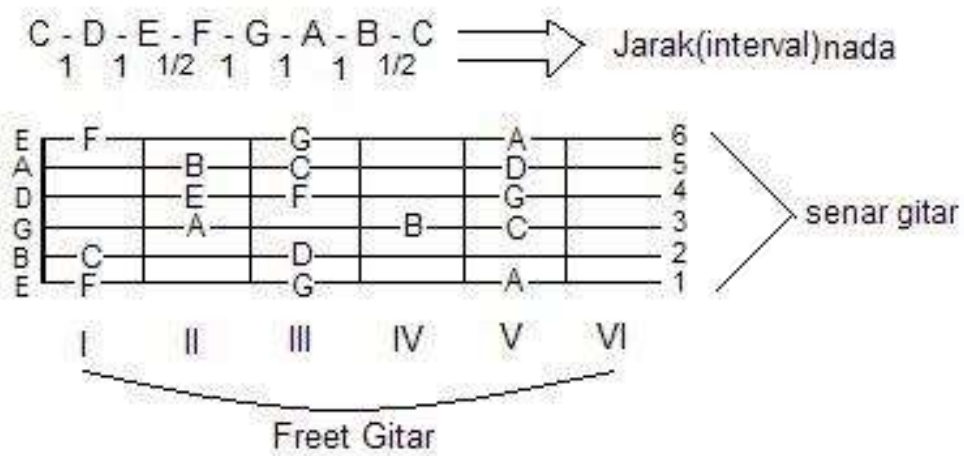

Gambar 1 Interval Nada pada Gitar

Akor (Triad) mayor, minor, diminished, dan augmented merupakan empat jenis akor utama yang harus dikuasai, khususnya bagi pemula, untuk dapat memainkan berbagai macam lagu. Setiap akor ini terdiri dari tiga nada dengan jarak yang berbeda. Dengan nada dasar C, berikut penjabaran masing-masing jenis akor:

- $\quad$ Akor C mayor terdiri dari nada $\mathrm{C}$, E, dan $\mathrm{G}$. Interval $\mathrm{C}$ ke $\mathrm{E}=2$, dan $\mathrm{E}$ ke $\mathrm{G}=1 \frac{1}{2}$.

- $\quad$ Akor C minor terdiri dari nada C, D\#/Eb, dan G. Interval C ke D\#/Eb = 11/2, dan D\#/Eb ke G = 2 .

- $\quad$ Akor $\mathrm{C}$ diminished terdiri dari nada $\mathrm{C}, \mathrm{D \# /Eb}$, dan F\#/Gb. Interval $\mathrm{C}$ ke $\mathrm{D \# /Eb}=1$ 1/2, dan $\mathrm{D \# /Eb} \mathrm{ke}$ $\mathrm{F} \# / \mathrm{Gb}=11 / 2$.

- $\quad$ Akord C augmented terdiri dari nada-nada C, E, dan G\#/Ab. Interval C ke E = 2, dan E ke G\#/Ab = 2 .

Hal lain yang perlu diperhatikan adalah bahwa di antara setiap nada yang berjarak 1, terdapat sebuah nada lagi yang berjarak $1 / 2$. Jika tangga nada tersebut diurai, maka akan menjadi:

$$
c-(c \# / d b)-d-(d \# / e b)-e-f-(f \# / g b)-g-(g \# / a b)-a-(a \# / b b)-b-c^{\prime}
$$

Tiap nada di atas berjarak $1 / 2$ nada. Kedua nada yang berada dalam tanda (), yang meskipun memiliki nama yang berbeda tetapi mempunyai bunyi yang sama, disebut juga sebagai nada Enharmonik.

Mobile dapat diartikan sebagai perpindahan yang mudah dari satu tempat ke tempat yang lain, misalnya telepon mobile berarti bahwa terminal telepon yang dapat berpindah dengan mudah dari satu tempat ke tempat lain tanpa terjadi pemutusan atau terputusnya komunikasi (Wulandari, 2013). Aplikasi mobile didefinisiskan oleh Quinn (2000) sebagai aplikasi yang dapat digunakan walaupun pengguna berpindah dengan mudah dari satu tempat ke tempat lain lain tanpa terjadi pemutusan komunikasi. Penelitian ini bertujuan merancang dan membuat aplikasi yang dapat memudahkan pengguna memahami berbagai bentuk akor gitar berdasarkan akor dasar dan nada pada gitar. Aplikasi mobile berbasis Android ini ditujukan untuk gitaris pemula dan hanya membahas materi dasar tentang gitar, akor dasar gitar, dan bentuk dari masing-masing akor dasar. Berikut perbandingan antara aplikasi ini (Guitar Chord For Beginner) dengan Guitar Chord Pro dari IronBill.

52 | Julius Saint Michael Lalela et al. : Pembuatan Aplikasi Pembelajaran... 
Tabel 1 Tabel Perbandingan Aplikasi

\begin{tabular}{|c|l|l|}
\hline \multirow{2}{*}{ No } & \multicolumn{2}{|c|}{ Nama Aplikasi } \\
\cline { 2 - 3 } & Guitar Chord For Beginner & \multicolumn{1}{|c|}{ Guitar Chord Pro } \\
\hline 1 & $\begin{array}{l}\text { Menu Kunci Dasar } \\
\text { YES }\end{array}$ & $\begin{array}{l}\text { Menu Kunci Dasar } \\
\text { YES }\end{array}$ \\
\hline 2 & $\begin{array}{l}\text { Bentuk Posisi Jari } \\
\text { YES }\end{array}$ & $\begin{array}{l}\text { Bentuk Posisi Jari } \\
\text { YES }\end{array}$ \\
\hline 3 & $\begin{array}{l}\text { Nada Kunci Gitar } \\
\text { YES }\end{array}$ & $\begin{array}{l}\text { Nada Kunci Gitar } \\
\text { YES }\end{array}$ \\
\hline
\end{tabular}

Dari Tabel 1 di atas, terlihat bahwa aplikasi Guitar Chord Pro hanya memiliki menu untuk menampilkan akor dasar gitar dan posisi jari pada gitar. Untuk memudahkan pengguna saat mengunakan aplikasi yang dibuat, pada aplikasi yang dibuat ditambahkan fitur nada gitar untuk memastikan bahwa nada yang akan dimainkan benar pada posisi jari yang tepat untuk suatu akor gitar.

\section{METODE}

Gambar 2 merupakan ilustrasi deskripsi umum system. User terlebih dahulu melihat berbagai bentuk chord gitar yang disediakan oleh sistem. Setelah user memilih akor, akan tampil gambar bentuk akor gitar beserta posisi jari tangan untuk memainkan akor tersebut. Jika user hendak mendengar nada dari bentuk akor gitar tersebut, misal agar tidak terjadi kesalahan bunyi nada dalam berlatih, user dapat menekan tombol yang tersedia.

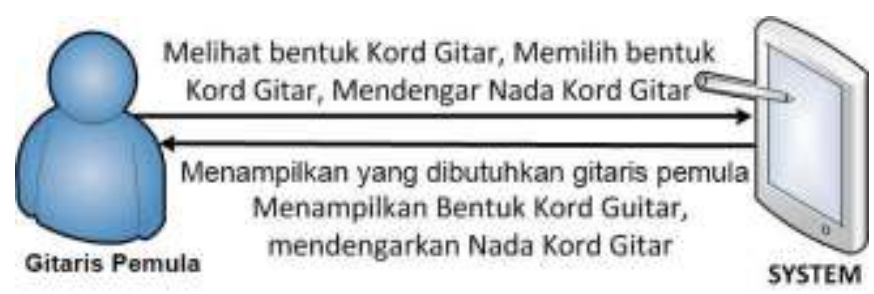

Gambar 2 Deskripsi Umum Sistem

Perangkat Lunak yang diperlukan untuk membuat aplikasi ini meliputi Adobe Flash CS5, Adobe Air, Android Emulator, Android SDK, Adobe Photoshop CS6, dan Sound Recorder (dari Windows 7). Di samping digunakan untuk keperluan pembuatan animasi biasa dan animasi situs web, Flash juga dapat digunakan untuk membuat game, presentasi, dan animasi kartun. Sekarang juga sudah mulai berkembang penggunaan Flash untuk pembuatan game di mobile device seperti handphone, PDA, dll (Akbar, 2008). Menurut Chambers (2008) Adobe Air adalah sebuah cross-operation-system runtime yang dikembangkan oleh Adobe untuk mengizinkan para web developer untuk memanfaatkan keahlian pengembangan web (seperti Flash, Flex, HTML, Java-Script, dan PDF) untuk membuat dan menyebarkan RIA dan konten ke desktop. Android SDK terdiri dari debugger, libraries, handset emulator, dokumentasi, contoh kode, dan tutorial. Harahap (2011) Android-SDK merupakan tools bagi para programmer yang ingin mengembangkan aplikasi berbasis Google Android. Perangkat Keras 
yang digunakan untuk membuat aplikasi ini terdiri dari sebuah smartphone Android dan laptop dengan spesifikasi sebagai berikut:

- Processor Genuine Intel Core i5 2.40Ghz (4 CPU's).

- 2GB RAM.

- Layar LED 13 inch.

- DVD-ROM drive.

- $\quad$ VGA ATI RADEON HD 4500 VRAM 1.35 GB.

Pada skenario use case aplikasi pembelajaran akor gitar berbasis mobile ini, dengan gitaris pemula sebagai aktor yang menggunakan aplikasi, sistem menyediakan beberapa bentuk akor gitar dasar yang nantinya akan dipelajari oleh user (C D E F G A B) beserta bentuk dari masing-masing dari akor dasar tersebut. Kemudian user juga dapat melihat posisi jari yang benar dalam memainkan akor gitar dan dapat mendengar nada pada akor gitar saat berlatih untuk memastikan bahwa nada yang dimainkan sudah benar.

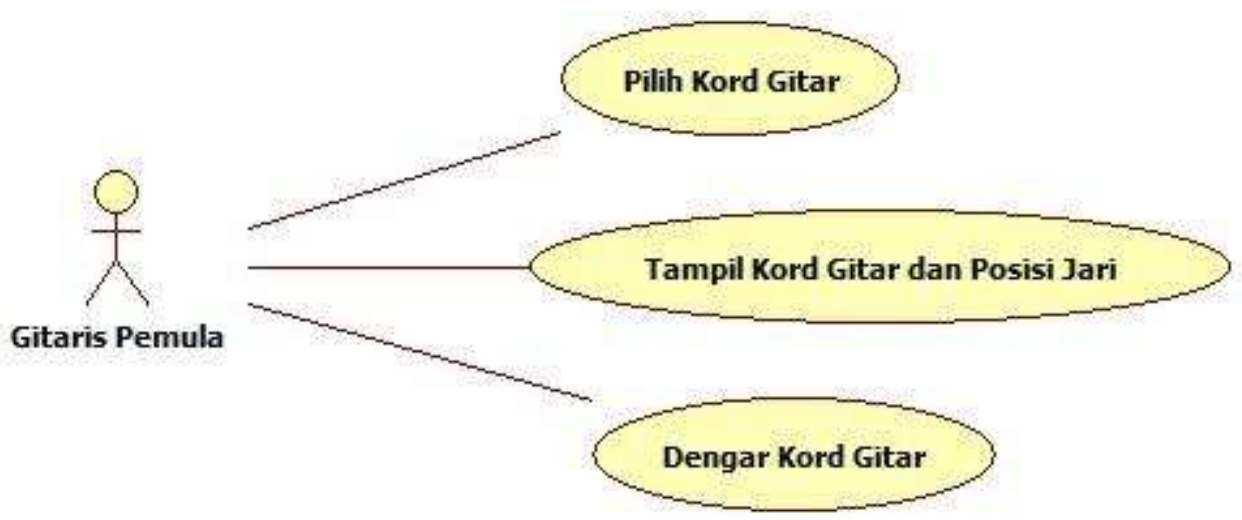

Gambar 3 Use case Diagram

Gambar 4 menampilkan analisis kelas. User dapat melihat tampilan utama aplikasi pada GUI menu utama, yang kemudian akan diproses pada controller kord (akor) untuk menampilan GUI menu kord (akor), yang akan diproses lebih lanjut pada controller bentuk kord (akor) yang kemudian akan menampilkan GUI bentuk akor. Pada GUI bentuk kord terdapat akor C, akor D, akor E, akor F, akor G, akor A, akor B. Kemudian, setiap bentuk kord akan mengalami proses suara yang akan mngeluarkan suara dari setiap bentuk akor yang dipilih.

54 | Julius Saint Michael Lalela et al. : Pembuatan Aplikasi Pembelajaran... 


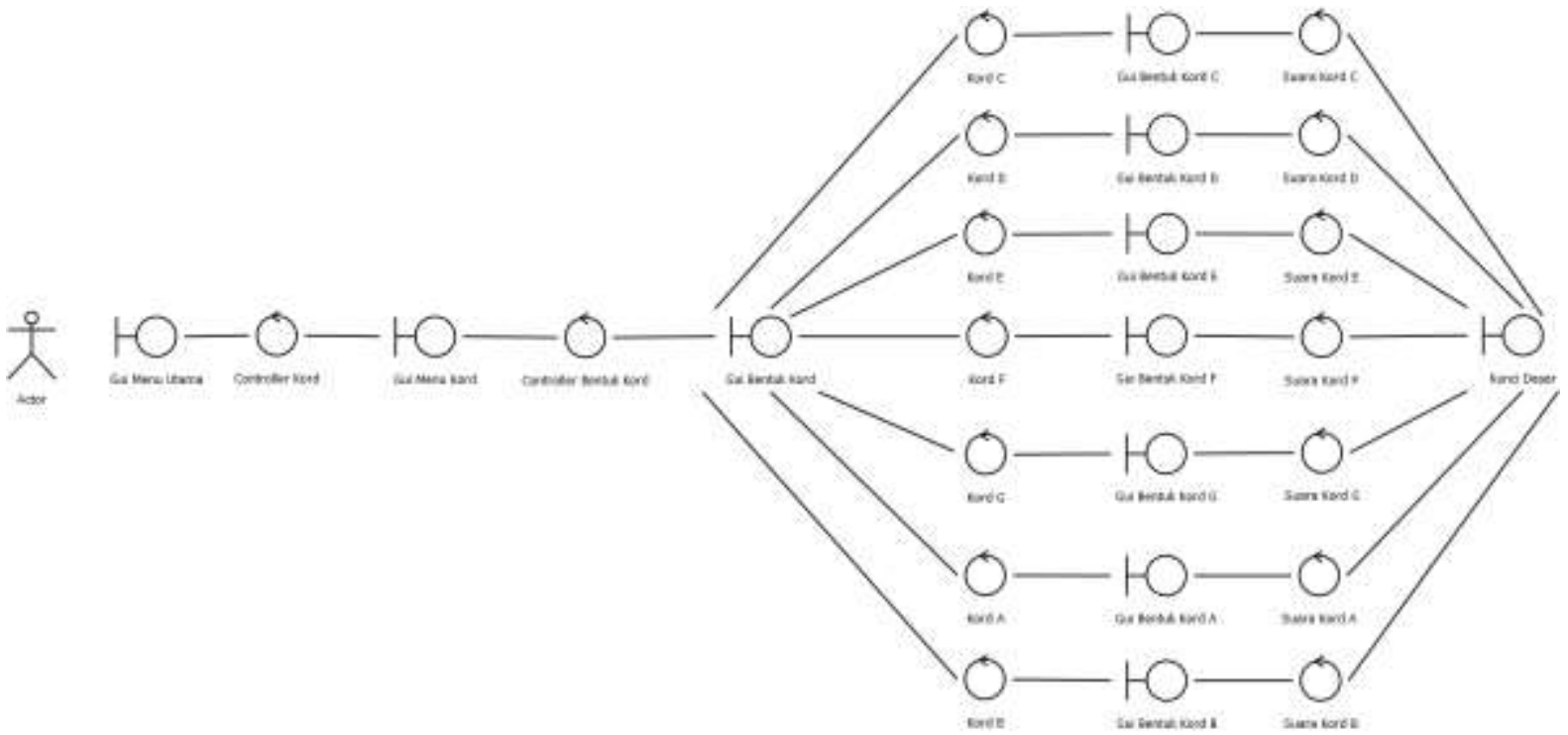

Gambar 4 Analisis Kelas

Gambar 5 menampilkan Sequence Diagram Pilih Kord Gitar. Berikut penjelasan lebih lanjut terkait diagram ini.

1. Tampil menu awal aplikasi

2. Proses menampilkan menu akor dasar gitar

3. Tampil menu akor dasar gitar

4. Proses menampilkan menu bentuk akor dari kunci dasar

5. Tampil menu bentuk akor dari kunci dasar

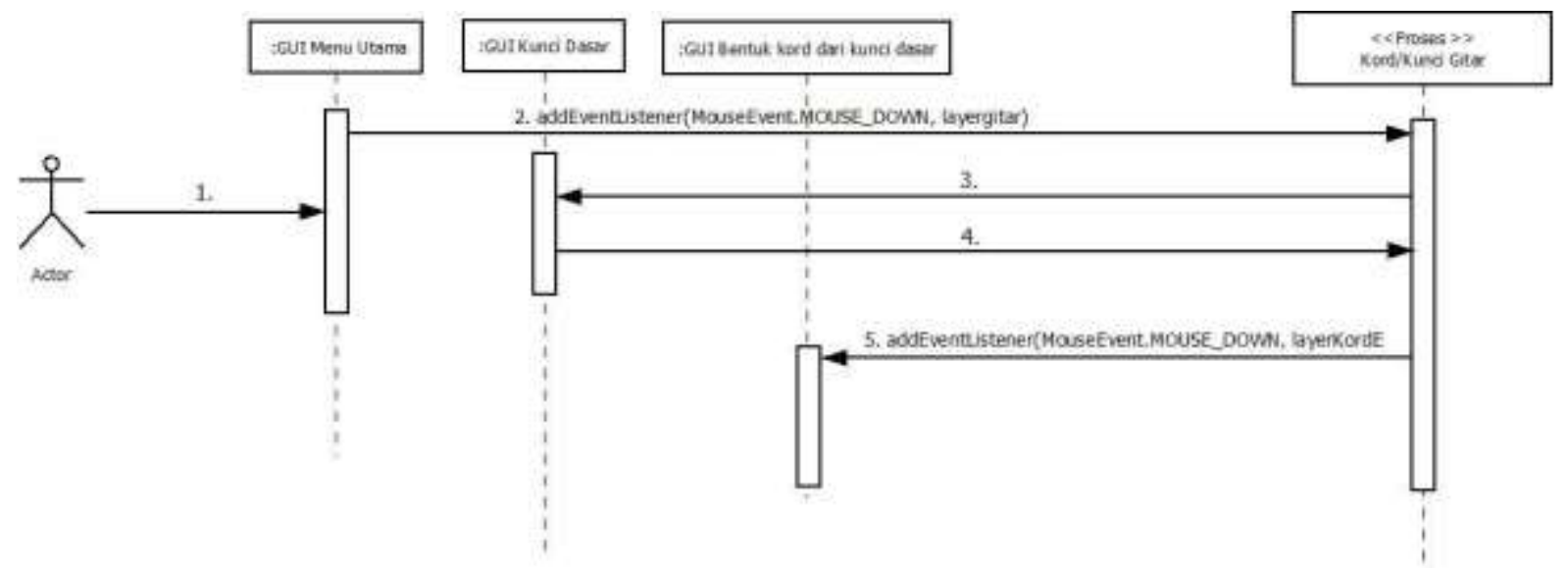

Gambar 5 Sequence Diagram Pilih Kord Gitar

Gambar 6 menampilkan Sequence Diagram Tampil Kord Gitar dan Posisi Jari. Berikut penjelasan lebih lanjut terkait diagram ini.

1. Tampil menu awal aplikasi

2. Proses menampilkan menu kunci dasar gitar

3. Tampil menu akor dasar gitar

4. Proses menampilkan menu bentuk akor dari kunci dasar 
5. Tampil menu bentuk akor dari kunci dasar

6. Proses Menampilkan posisi jari

7. Tampil Posisi Jari berdasarkan bentuk akor dari kunci dasar

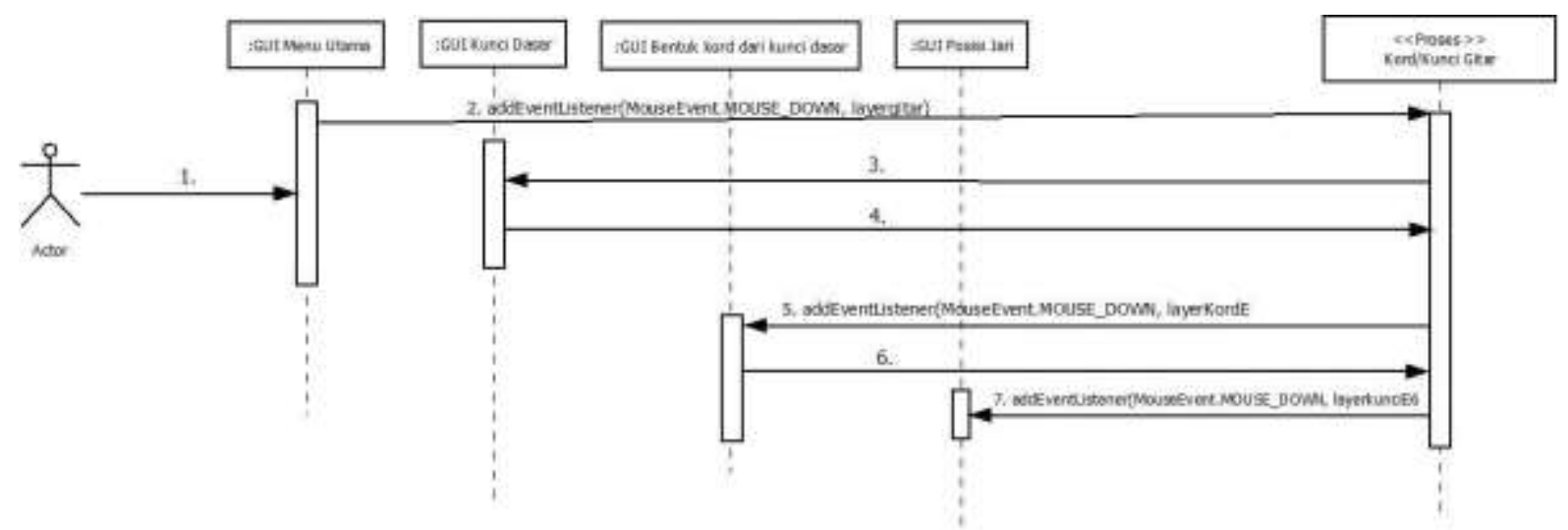

Gambar 6 Sequence Diagram Tampil Kord Gitar dan Posisi Jari

Gambar 7 menampilkan Sequence Diagram Dengar Kord Gitar dan Posisi Jari. Berikut penjelasan lebih lanjut terkait diagram ini.

1. Tampil menu awal aplikasi

2. Proses menampilkan menu kunci dasar gitar

3. Tampil menu akor dasar gitar

4. Proses menampilkan menu bentuk akor dari kunci dasar

5. Tampil menu bentuk akor dari kunci dasar

6. Proses menampilkan posisi jari

7. Tampil posisi jari berdasarkan bentuk akor dari kunci dasar

8. Proses mendengar nada/suara akor gitar

9. Mendengar nada akor gitar

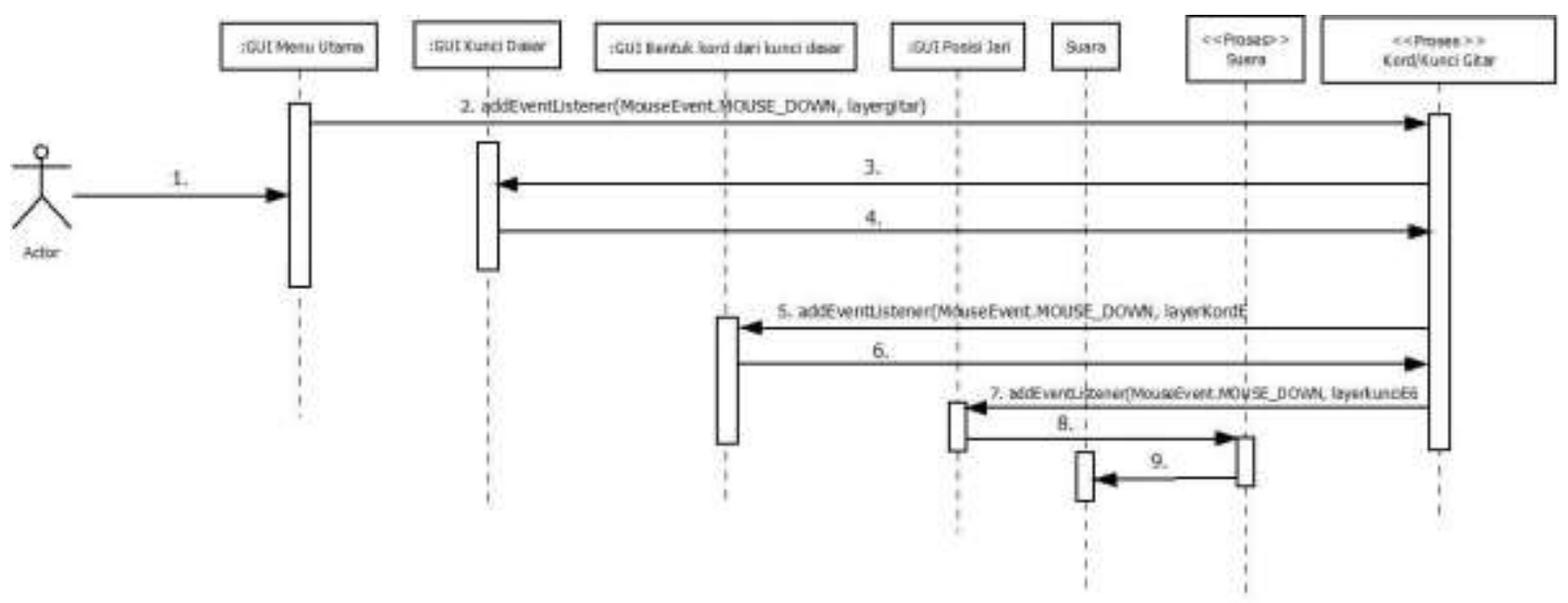

Gambar 7 Sequence Diagram Dengar Kord Gitar

56 | Julius Saint Michael Lalela et al. : Pembuatan Aplikasi Pembelajaran... 


\section{HASIL DAN PEMBAHASAN}

Untuk memberi hasil yang optimal, maka uji coba dilakukan pada Android emulator dan smartphone Android. Pada Android emulator, aplikasi berjalan dengan baik dan lancar karena aplikasi Adobe Air sudah terpasang. Secara lebih jelas, uji coba dengan Android emulator diilustrasikan dalam gambar 8.

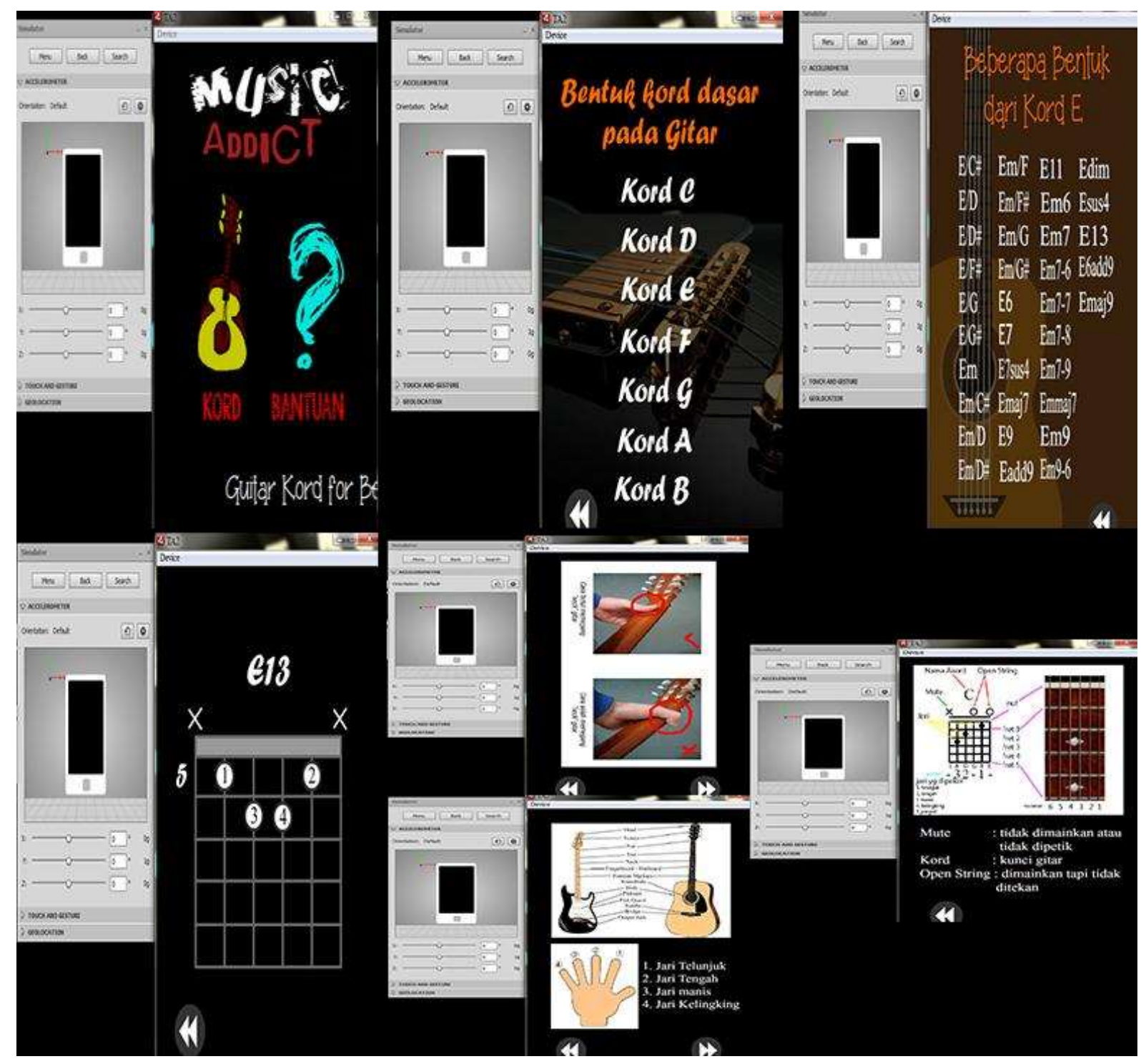

Gambar 8 Pengujian pada Emulator Android

Smartphone yang digunakan untuk pengujian aplikasi ini adalah Samsung Galaxy Note 2 model GT-N7105 dengan OS Android 4.1.2 Jelly Bean. Aplikasi berjalan dengan baik dan lancar karena pada smartphone sudah terpasang aplikasi Adobe Air. Hasil pengujian dengan smartphone dapat dilihat pada gambar 9. 


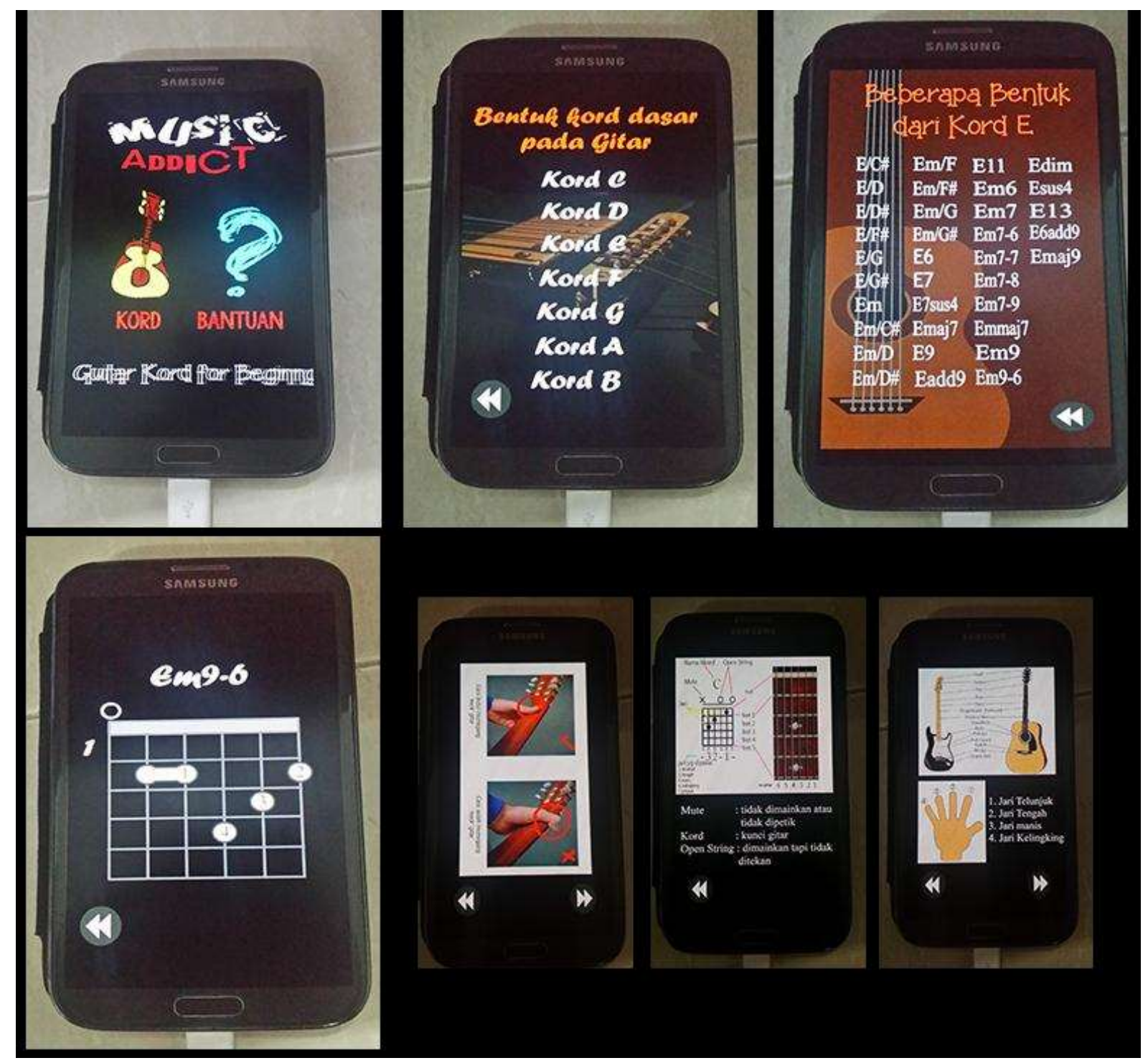

Gambar 9 Pengujian pada Smartphone

Gambar 10 mengilustrasikan proses untuk menampilkan menu tampilan akor dasar gitar. Terdapat mouse event (MOUSE_DOWN) dan fungsi gotoandstop yang akan masuk ke frame 2.

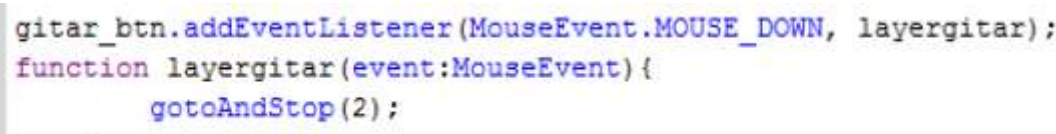

\section{Gambar 10 Proses Akor}

Gambar 11 mengilustrasikan proses untuk menampilkan berbagai bentuk akor berdasarkan akor dasar. Terdapat mouse event (MOUSE_DOWN), dan fungsi gotoandstop yang akan masuk ke frame 4 . 


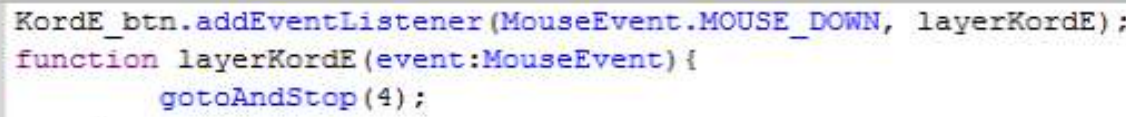

Gambar 11 Proses Bentuk Kord

Gambar 12 menjelaskan proses suara pada salah satu bentuk akor gitar, akor G/E pada kunci dasar G.
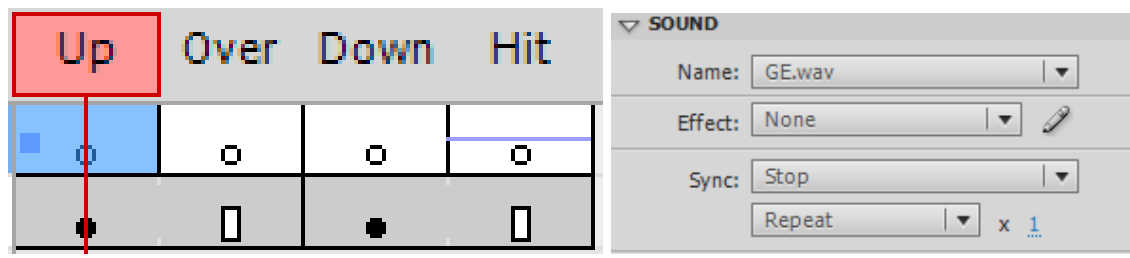

Gambar 12 Proses Suara

Tabel 2 berisi rangkuman hasil pengujian yang dilakukan.

Tabel 2 Rangkuman Hasil Pengujian

\begin{tabular}{|l|l|l|l|l|}
\hline Kasus Uji & Langkah Pengujian & Hasil yang Diharapkan & Hasil Aktual & Kesimpulan \\
\hline $\begin{array}{l}\text { Tampil } \\
\text { akor dasar }\end{array}$ & $\begin{array}{l}\text { Pada tampilan menu } \\
\text { utama, klik ikon gitar }\end{array}$ & $\begin{array}{l}\text { Akan tampil menu tampilan } \\
\text { akor dasar. }\end{array}$ & $\begin{array}{l}\text { Menu tampilan akor } \\
\text { dasar tampil tanpa } \\
\text { pesan } \text { error. }\end{array}$ & diterima \\
\hline $\begin{array}{l}\text { Tampil } \\
\text { bentuk } \\
\text { akor gitar }\end{array}$ & $\begin{array}{l}\text { Dari menu tampilan akor } \\
\text { dasar, pilih salah satu } \\
\text { akor dasar yang ingin } \\
\text { dimainkan. }\end{array}$ & $\begin{array}{l}\text { Akan tampil menu tampilan } \\
\text { bentuk akor dari akor dasar } \\
\text { yang dipilih. }\end{array}$ & $\begin{array}{l}\text { Tampilan bentuk akor } \\
\text { gitar muncul tanpa } \\
\text { pesan } \text { error. }\end{array}$ & diterima \\
\hline $\begin{array}{l}\text { Tampil } \\
\text { posisi jari }\end{array}$ & $\begin{array}{l}\text { Pilih salah satu bentuk } \\
\text { akor yang telah dipilih } \\
\text { dari akor dasar yang } \\
\text { ingin dimainkan }\end{array}$ & $\begin{array}{l}\text { Akan tampil posisi jari bentuk } \\
\text { akor gitar yang dipilih. }\end{array}$ & $\begin{array}{l}\text { Tampilan posisi jari } \\
\text { muncul tanpa pesan } \\
\text { error. }\end{array}$ & diterima \\
\hline $\begin{array}{l}\text { Dengar } \\
\text { suara }\end{array}$ & $\begin{array}{l}\text { Pada tampilan posisi jari } \\
\text { yang telah dipilih, klik } \\
\text { tombol dengan ikon } \\
\text { suara yang berada di } \\
\text { bagian kanan bawah. }\end{array}$ & $\begin{array}{l}\text { Akan terdengar suara dari } \\
\text { bentuk akor gitar yang dipilih } \\
\text { saja. }\end{array}$ & $\begin{array}{l}\text { Terdengar suara dari } \\
\text { tombol yang ditekan } \\
\text { berdasarkan bentuk } \\
\text { akor gitar yang dipilih } \\
\text { saja. }\end{array}$ & diterima \\
\hline $\begin{array}{l}\text { Tampil } \\
\text { bantuan } \\
\text { utama klik ikon tanda } \\
\text { tanya warna biru. }\end{array}$ & $\begin{array}{l}\text { Akan muncul gambar bantuan } \\
\text { yang akan menjelaskan } \\
\text { bagian-bagian penggunaan } \\
\text { aplikasi, bagian-bagian gitar, } \\
\text { dan cara memegang neck gitar }\end{array}$ & $\begin{array}{l}\text { Gambar tampil tanpa } \\
\text { pesan } \text { error. }\end{array}$ & diterima \\
\hline
\end{tabular}

\section{KESIMPULAN}

Dari uraian di atas, aplikasi ini mampu memudahkan pengguna dalam mengenal berbagai bentuk akor (baik akor dasar maupun akor-akor lain) berdasarkan akor dasar yang ada pada gitar, mencari akor gitar, dan mengenal nada pada setiap akor gitar yang dimainkan. Tuner gitar merupakan fitur penting yang dapat ditambahkan untuk mempermudah gitaris pemula menyetem gitar sehingga nada dan akor yang dimainkan 
sesuai dengan yang dikehendaki. Selain itu, diperlukan pula sedikit pengenalan tentang gitar dan cara memainkan gitar dengan benar.

\section{DAFTAR PUSTAKA}

Akbar, M.A. (2008). Pengertian Flash. Dikutip dari http//www.penngertian-flash-2008

Chambers, M. (2008). Adobe AIR for JavaScript Developers Pocket Guide (1st Edition). Sebastopol: O'Reilly Media.

Harahap, N.S. (2012) Pemrograman Aplikasi Mobile Smartphone dan Tablet Pc Berbasis Android. Bandung: Informartika Bandung.

Quinn, C., (2000). M-learning: Mobile, Wireless and In-Your-Pocket Learning. Dikutip dari http://linezine.com/3.1/features/cwdfmw.htm

Wulandari, N.R. (2013). Aplikasi Ujian Via SMS Berbasis SMS Gateway Menggunakan Metode Waterfall. Lampung: Fakultas MIPA Universitas Lampung.

60 | Julius Saint Michael Lalela et al. : Pembuatan Aplikasi Pembelajaran... 